\title{
Viral Vector-Mediated Overexpression of Estrogen Receptor- $\alpha$ in Striatum Enhances the Estradiol-Induced Motor Activity in Female Rats and Estradiol-Modulated GABA Release
}

\author{
Kristin N. Schultz, ${ }^{2}$ Silke A. von Esenwein, ${ }^{6,7}$ Ming Hu, ${ }^{1}$ Amy L. Bennett, ${ }^{8}$ Robert T. Kennedy, ${ }^{2,3}$ Sergei Musatov, ${ }^{9}$ \\ C. Dominique Toran-Allerand, ${ }^{10,11}$ Michael G. Kaplitt, ${ }^{12}$ Larry J. Young, ${ }^{6,13}$ and Jill B. Becker ${ }^{1,4,5}$ \\ ${ }^{1}$ Molecular and Behavioral Neuroscience Institute and Departments of ${ }^{2}$ Chemistry, ${ }^{3}$ Pharmacology, ${ }^{4}$ Psychology, and ${ }^{5}$ Psychiatry, University of Michigan, \\ Ann Arbor, Michigan 48109, ${ }^{6}$ Center for Behavioral Neuroscience and ${ }^{7}$ Psychology Department, Emory University, Atlanta, Georgia 30322, ${ }^{8}$ Department of \\ Psychology, Towson University, Towson, Maryland 21252, ${ }^{9}$ Neurologix, Inc., Fort Lee, New Jersey 07024, Departments of ${ }^{10}$ Anatomy and Cell Biology and \\ ${ }^{11}$ Neurology, Columbia University College of Physicians and Surgeons, New York, New York 10027, ${ }^{12}$ Department of Neurological Surgery, Weill Medical \\ College of Cornell University, New York, New York 10065, and ${ }^{13}$ Department of Psychiatry and Behavioral Sciences, Yerkes National Primate Research \\ Center, Emory University School of Medicine, Atlanta, Georgia 30322
}

Classical estrogen receptor-signaling mechanisms involve estradiol binding to intracellular nuclear receptors [estrogen receptor- $\alpha$ $(\mathrm{ER} \alpha)$ and estrogen receptor- $\beta(\mathrm{ER} \beta)]$ to promote changes in protein expression. Estradiol can also exert effects within seconds to minutes, however, a timescale incongruent with genomic signaling. In the brain, estradiol rapidly potentiates stimulated dopamine release in the striatum of female rats and enhances spontaneous rotational behavior. Furthermore, estradiol rapidly attenuates the $\mathrm{K}^{+}$-evoked increase of GABA in dialysate. We hypothesize that these rapid effects of estradiol in the striatum are mediated by ER $\alpha$ located on the membrane of medium spiny GABAergic neurons. This experiment examined whether overexpression of ER $\alpha$ in the striatum would enhance the effect of estradiol on rotational behavior and the $\mathrm{K}^{+}$-evoked increase in GABA in dialysate. Ovariectomized female rats were tested for rotational behavior or underwent microdialysis experiments after unilateral intrastriatal injections of a recombinant adeno-associated virus (AAV) containing the human $\operatorname{ER} \alpha$ cDNA (AAV.ER $\alpha$ ) into the striatum; controls received either the same vector into areas outside the striatum or an AAV containing the human alkaline phosphatase gene into the striatum (AAV.ALP). Animals that received AAV.ER $\alpha$ in the striatum exhibited significantly greater estradiol-induced contralateral rotations compared with controls and exhibited behavioral sensitization of contralateral rotations induced by a low-dose of amphetamine. ER $\alpha$ overexpression also enhanced the inhibitory effect of estradiol on $\mathrm{K}^{+}$-evoked GABA release suggesting that disinhibition of dopamine release from terminals in the striatum resulted in the enhanced rotational behavior.

Key words: estradiol; dopamine; rotational behavior; microdialysis; striatum; adeno-associated viral vector; estrogen receptor

\section{Introduction}

Estradiol rapidly enhances stimulated dopamine (DA) release from striatum in vitro (Becker, 1990a; Xiao and Becker, 1998;

\footnotetext{
Received Sept. 27, 2008; revised Dec. 16, 2008; accepted Jan. 4, 2009.

This work was supported by National Institutes of Health (NIH) Grants DA12677, NSF IBN9816673, and NS048141 to J.B.B.; and National Science Foundation agreements IBN-9876754 and R37 EB003320 to R.T.K. M.H. and K.N.S were supported by the NIH under the Ruth L. Kirschstein National Research Service Award T32 DA007267. We thank Dr. Geoffrey Greene (University of Chicago) for his gift of the H222 estrogen receptor antibody. We also thank Dr. Thomas Insel (National Institute of Mental Health) for his comments on an earlier version of this manuscript and for his encouragement and support throughout this project.

Correspondence should be addressed to Dr. Jill B. Becker, Molecular and Behavioral Neuroscience Institute, 205 Zina Pitcher Place, Ann Arbor, Ml 48109. E-mail: jbbecker@umich.edu.

S. A. von Esenwein's present address: Department of Health Policy and Management, Rollins School of Public Health, Emory University, Atlanta, GA 30322.

M. Hu's present address: Discovery Pharmacology, Sepracor, Inc., Marlborough, MA 01752.

DOI:10.1523/JNEUROSCI.4647-08.2009

Copyright $\odot 2009$ Society for Neuroscience $\quad$ 0270-6474/09/291897-07\$15.00/0
}

Xiao et al., 2003) or in vivo (Becker, 1990b; Castner et al., 1993). This rapid effect of estradiol on striatal DA is thought to contribute to the enhanced acquisition of cocaine self-administration and enhanced motivation to take cocaine found in female rats after estradiol treatment (Jackson et al., 2006; Becker and $\mathrm{Hu}$, 2008; Hu and Becker, 2008).

DA release in striatum is inhibited by intrinsic GABA input (Smolders et al., 1995; Whitehead et al., 2001), so we hypothesized that estradiol enhances DA release in the striatum indirectly via inhibition of GABA input onto DA terminals. In whole-cell clamp recordings, application of physiological concentrations of $17 \beta$-estradiol decreases $\mathrm{Ca}^{2+}$ current mediated by L-type $\mathrm{Ca}^{2+}$ channels in acutely dissected medium spiny neurons within seconds of application (Mermelstein et al., 1996). Since inhibition of L-type $\mathrm{Ca}^{2+}$ channels on cell bodies decreases neurotransmitter release from neurons (Vigh and Lasater, 2004), and striatal me- 
dium spiny neurons are GABAergic, this would suggest that estradiol can inhibit GABA release. In microdialysis experiments estradiol significantly attenuates the $\mathrm{K}^{+}$-evoked increase in GABA in dialysate from the striatum (Hu et al., 2006) supporting this hypothesis.

Activation of membrane-associated estrogen receptor- $\alpha$ $(\mathrm{ER} \alpha)$ and/or estrogen receptor- $\beta(\mathrm{ER} \beta)$ may mediate some of the rapid effects of estradiol in striatum, and other brain regions, through a novel mechanism (Boulware et al., 2007; Micevych and Mermelstein, 2008). ER $\alpha$ and/or ER $\beta$ can associate with caveolin in the extracellular membrane of cells to mediate rapid responses to estradiol. For example, extracellular estradiol can rapidly activate the mitogen-activated protein kinase pathway, one of the primary mediators of the intracellular signal transduction cascade triggered by estradiol binding to $\mathrm{ER} \alpha$ at the membrane (Razandi et al., 2003; Wade and Dorsa, 2003). Whether estradiol acts in the striatum via $\mathrm{ER} \alpha$ to influence behavior or GABA release remains to be determined.

These experiments investigate the effects of overexpression of $\mathrm{ER} \alpha$ in the striatum. Female rats have an endogenous asymmetry in the ascending DA system, so they turn in circles away from the striatum with greater DA activity (Jerussi and Glick, 1976; Becker et al., 1982), and turn more during behavioral estrus than on other days of the cycle (Becker et al., 1982). We took advantage of this estradiol-modulated behavioral and neurochemical asymmetry to investigate whether overexpression of $\mathrm{ER} \alpha$ in striatum would enhance the effect of estradiol on this behavior. We also investigate whether ER $\alpha$ overexpression would enhance the effect of estradiol on the $\mathrm{K}^{+}$-evoked increase in GABA in dialysate from striatum. The results demonstrate that increasing expression of $\mathrm{ER} \alpha$ unilaterally in the striatum enhances the rapid behavioral effect of estradiol and induces greater attenuation of $\mathrm{K}^{+}$-evoked GABA release after estradiol treatment compared with control animals. Furthermore, we demonstrate that in the striatum of adult ovariectomized rats there is low-level expression of $\mathrm{ER} \alpha$ protein. These results indicate that endogenous $\mathrm{ER} \alpha$ may mediate rapid effects of estradiol on GABA activity and striatal-mediated behaviors observed in the female rat.

\section{Materials and Methods}

\section{Animals}

Adult female Sprague Dawley rats (Harlan) were maintained on a 14:10 light/dark cycle with soy-free rat chow (Teklad \#2014, Harlan rat chow) and water available ad libitum. Rooms were maintained at a constant temperature of $20-21^{\circ} \mathrm{C}$. For the behavioral experiments animals were housed in groups of $2-3$ with lights on at 6:30 P.M. For the microdialysis experiments, animals were individually housed after guide cannula implantation, and lights in the colony room were on at 5:30 A.M. All experiments were conducted in accordance with the National Institute of Health guidelines on a protocol approved by the University of Michigan Committee for Use and Care of Animals.

Rats were ovariectomized (OVX) under isoflurane (Baxter Healthcare Corporation) anesthesia (Hu and Becker, 2003), and those undergoing behavioral testing were tested for rotational behavior 2 weeks later with $0.85 \mathrm{mg} / \mathrm{kg}$ D-amphetamine (AMPH) sulfate ( 1 h test on 3 consecutive days). Rats then received intrastriatal injections of the viral vector [adeno-associated virus (AAV) with $\operatorname{ER} \alpha$; AAV.ER $\alpha ; N=14$; see below for details] or control construct (adeno-associated virus with the enzyme alkaline phosphatase; AAV.ALP; $N=9$ ) into three sites, unilaterally in the striatum contralateral to preferred direction of turning (i.e., into the dominant striatum). On histological examination, four of the animals in the AAV.ER $\alpha$ group did not have ER expression in striatum (the expression was only in cortex) and data from these animals are included with the control group (final groups AAV.ER $\alpha ; N=10$, AAV.ALP; $N=13$ ).
Adeno-associated viral vectors

Experimental animals received an AAV containing the human $\mathrm{ER} \alpha$ cDNA (AAV.ER $\alpha$ ). Control animals received an AAV harboring the human placental alkaline phosphatase gene (AAV.ALP). The expression of the transgenes was driven by the chicken $\beta$-actin/cytomegalovirus hybrid promoter (CAG). In addition, an internal ribosomal entry site element provides a bicistronic expression of enhanced green fluorescent protein (GFP) from both constructs to permit visualization of transduced neurons. The expression cassettes were flanked by AAV inverted terminal repeats derived from psub201 (Samulski et al., 1987).

Preparation of adeno-associated viral vector stocks. To prepare virus stocks, the vector plasmids were packaged into AAV-2 particles using helper-free plasmid transfection system in 293 cells. The vectors were purified using heparin affinity chromatography (Clark et al., 1999) and dialyzed against PBS. Genomic titers were determined by quantitative PCR (Veldwijk et al., 2002) and adjusted to $10^{12}$ particles per ml.

Injection of viral vector unilaterally into striatum. OVX female rats underwent stereotaxic surgery under ketamine $(75 \mathrm{mg} / \mathrm{kg}$, i.p. $)$ and medetomidine hydrochloride $(0.5 \mathrm{mg} / \mathrm{kg}$, i.p. $)$ anesthesia. Small burr holes were drilled through the skull immediately above the dominant striatum (determined by AMPH-induced behavior as described above) with a drill mounted on a stereotaxic arm. Three holes were drilled and a microsyringe was slowly lowered over $2 \mathrm{~min}$ to the following coordinates: (1): Ant +1.0 , Lat \pm 2.0 , Ventral 2.7; (2) Ant +0.15 , Lat \pm 3.5 , Ventral 3.0; (3) Ant -0.75 , Lat \pm 3.8 , Ventral 3.0. At each site, $1 \mu$ l of the AAV was injected over 7-10 $\mathrm{min}$, the needle was left in place for an additional 2 min and then the needle was slowly raised.

\section{Behavioral testing}

Animals were tested repeatedly for rotational behavior. As discussed above, in unlesioned female rats there is an endogenous asymmetry in turning behavior seen during the dark phase of the cycle or with a low dose of AMPH (Jerussi and Glick, 1976; Becker et al., 1982). We hypothesized that enhanced expression of $\mathrm{ER} \alpha$ unilaterally in the striatum would induce a greater asymmetry in the striatum, and we would see greater rotational behavior after estradiol or in response to AMPH in animals with enhanced expression of the $\mathrm{ER} \alpha$ transgene. Thus, animals were repeatedly tested for rotational behavior after acute estradiol, oil, and/or AMPH injection.

Estradiol-induced turning. Three weeks after the viral vector had been injected into the brain, animals were repeatedly tested in automated rotometers for turning behavior ( $\mathrm{Hu}$ and Becker, 2003). Testing was initiated during the first hour after lights off in the colony. There was a $1 \mathrm{~h}$ habituation session, then animals received $5 \mu \mathrm{g}$ estradiol benzoate (EB) in $0.1 \mathrm{ml}$ peanut oil or $0.1 \mathrm{ml}$ peanut oil by subcutaneous injection, followed by a $1 \mathrm{~h}$ test session. Rotational behavior was recorded by computer at 15 min intervals.

Animals received 3 tests/week (2 with EB, 1 with oil) every other day for 2 weeks, then had 1 week off when they were tested with AMPH (see below), followed by 1 additional week of testing with EB and oil for a total of $6 \mathrm{~EB}$ tests and 3 oil tests. The first $15 \mathrm{~min}$ of the habituation periods and postinjection test periods were used for analyses, since animals exhibited the greatest activity during these periods.

AMPH-induced turning. On 3 consecutive days, 5 weeks after the viral vector had been injected into the striatum, animals received $\mathrm{EB}$ or oil (EB on days 1 and 3, oil on day 2). Animals were injected with EB or oil, placed in the automated rotometers, and 30 min later animals received $0.85 \mathrm{mg} / \mathrm{kg}$ AMPH (i.p.); rotational behavior was recorded for $1 \mathrm{~h}$.

Serum concentrations of estradiol at the time of the test were determined in independent groups of OVX animals of the same size using an immunofluorescent assay: $184.5 \pm 38.3$ (17 $\beta$-estradiol in $\mathrm{pg} / \mathrm{ml} \pm$ SEM; day 1 and 3 ) and $109.5 \pm 19.2$ (day 2). These values were not significantly different from each other, and were within the range of values reported for this strain of rat during proestrus (Butcher et al., 1974). Thus, on all $3 \mathrm{~d}$ animals had elevated serum estradiol concentrations relative to OVX animals, which we measured as $23.6 \pm 2.5 \mathrm{pg} / \mathrm{ml}$ (Hu et al., 2004).

\section{Guide cannula and microdialysis probe implantation}

At least 4 weeks after insertion of the viral vector, a separate group of rats were anesthetized using a combination of ketamine and medetomidine 


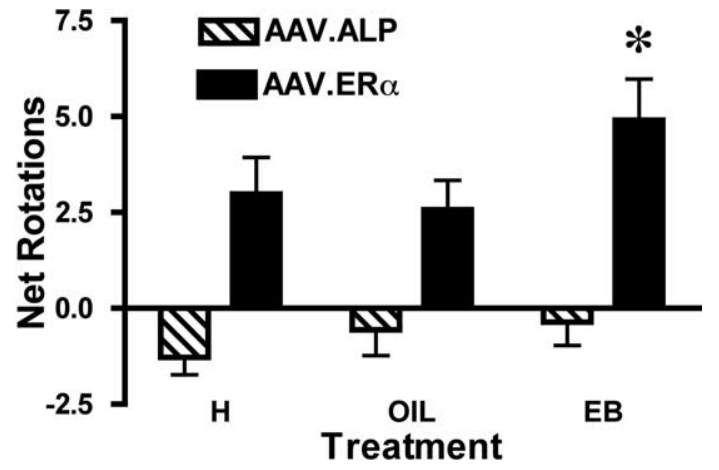

Figure 1. Full turns $\left(360^{\circ}\right)$ made contralateral to the striatum with the AAV.ER $\alpha$ or AAV.ALP transgene minus turns in the opposite direction during the first $15 \mathrm{~min}$ of the habituation period (H), the first $15 \mathrm{~min}$ after animals received $0.1 \mathrm{ml}$ peanut oil (OIL; S.C.) or the first $15 \mathrm{~min}$ after 5 $\mu g$ EB in oil (s.c.). *Animals with the AAV.ER $\alpha$ transgene expressed unilaterally in the striatum turned significantly more $(p<0.01)$ after EB than during the habituation period or after OIL and turned more than the control animals $(p<0.01)$. Bars indicate the mean \pm SEM.

hydrochloride anesthesia as outlined previously. Using aseptic surgical techniques, guide cannulas were implanted stereotaxically through the skull (from Bregma skull flat in mm, AP: $+0.2 \mathrm{~mm}$; ML: $+/-3.2 \mathrm{~mm}$; DV: $-2.25 \mathrm{~mm}$ ) and secured with cranioplastic cement. A stylet was placed in the guide cannula to keep the cannula patent.

After a minimum 1-week recovery period, the animal was lightly anesthetized with isoflurane (Baxter Healthcare Corporation), and a microdialysis probe (4 mm active length $\mathrm{CMA} / 11$, CMA/Microdialysis $\mathrm{AB}$ ) was inserted into the guide cannula. The animal was placed inside a Raturn (BioAnalytical Systems) bowl and artificial cerebral spinal fluid (aCSF: $145 \mathrm{~mm} \mathrm{NaCl}, 2.68 \mathrm{~mm} \mathrm{KCl}, 1.01 \mathrm{~mm} \mathrm{MgSO}_{4}{ }^{\star} 7 \mathrm{H}_{2} \mathrm{O}, 1.22 \mathrm{~mm}$ $\mathrm{CaCl}_{2}, \mathrm{pH} 7.3$ ) was perfused through the probe at $0.1 \mu \mathrm{l} / \mathrm{min}$ overnight.

\section{Microdialysis and determination of GABA concentrations in dialysate}

Experiments began 15-18 h after implantation of the dialysis probe. aCSF was perfused through the probe at $1 \mu \mathrm{l} / \mathrm{min}$, and on-line analysis of the dialysate was performed using capillary electrophoresis with laserinduced fluorescence detection, which has been described previously (Bowser and Kennedy, 2001). Briefly, dialysate was mixed online with a derivatization solution $(10 \mathrm{~mm} \quad o$-phthaldialdehyde, $40 \mathrm{~mm}$ $\beta$-mercaptoethanol, $36 \mathrm{~mm}$ sodium borate, $0.81 \mathrm{~mm}$ hydroxypropyl- $\beta$ cyclodextrin ( $\mathrm{HPbCD})$, and $10 \%$ methanol (v/v) at $\mathrm{pH} 9.5)$ and allowed to react for $90 \mathrm{~s}$. The derivatized dialysate was then electrokinetically injected onto the separation capillary ( $10 \mu \mathrm{m}$, i.d.; $150 \mu \mathrm{m}$, o.d.; and 9.5 $\mathrm{cm}$ in length) with a flow-gated interface. Cross flow buffer $(40 \mathrm{~mm}$ sodium tetraborate with $0.9 \mathrm{~mm} \mathrm{HPbCD}$ at $\mathrm{pH} 9.5$ ) prevented leakage of dialysate onto the separation capillary during each separation. The applied voltage for separation equated to an electric field of $-2.22 \mathrm{kV} / \mathrm{cm}$. Fluorescence detection was performed off-column with the aid of a sheath-flow cuvette. The sheath flow buffer consisted of $40 \mathrm{~mm}$ sodium tetraborate at $\mathrm{pH} 9.5$. Fluorescence was induced with the $351 \mathrm{~nm}$ laser line of an argon ion laser (Enterprise 622 argon ion laser; Coherent), and fluorescence emission $(450 \mathrm{~nm}$ ) was collected orthogonally to the incident beam. Data were collected using software written in Labview 5.0 (National Instruments). The detection limit for GABA in these assays was $15.1 \pm 0.7 \mathrm{~nm}$.

For each experiment, 50 electropherograms were collected at $15 \mathrm{~s}$ interval to establish basal levels before a subcutaneous injection of $5 \mu \mathrm{g} \mathrm{EB}$ $(N=19)$ or vehicle (peanut oil, $0.1 \mathrm{ml}, N=17)$. Electropherograms were collected for $30 \mathrm{~min}$ after vehicle/EB administration to determine the effect of EB on basal GABA release. Then high potassium aCSF $(75 \mathrm{~mm}$ $\mathrm{K}^{+}$) was perfused through the probe for $10 \mathrm{~min}$. The ionic strength of the aCSF was maintained by lowering the sodium concentration to $72.7 \mathrm{~mm}$. Electropherograms collected during the $10 \mathrm{~min}$ stimulation and $30 \mathrm{~min}$ poststimulation period were used to determine effects of estradiol on stimulated GABA release.

Once the dialysis experiment was complete, Flurogold (Molecular Im-

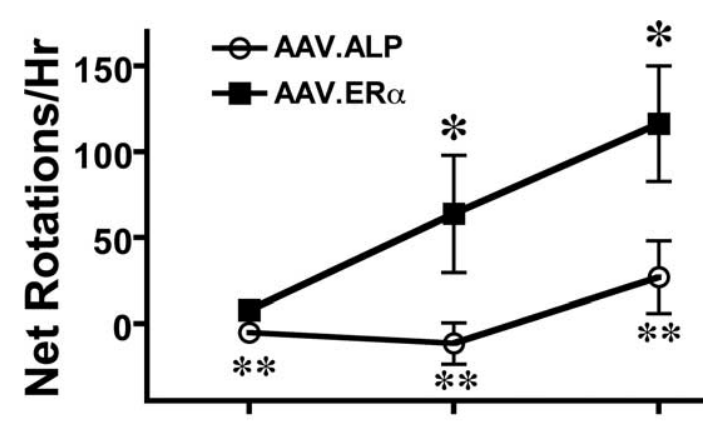

1 2 DAY

Figure 2. Animals with the AAV.ER $\alpha$ transgene expressed unilaterally in the striatum exhibited sensitization of asymmetrical rotational behavior when treated with $5 \mu \mathrm{g}$ EB followed $30 \mathrm{~min}$ later with $0.85 \mathrm{mg} / \mathrm{kg}$ D-amphetamine (AMPH). Rotational behavior contralateral to the side with the ER $\alpha$ transgene (minus turns in the other direction) was recorded for $1 \mathrm{~h}$ after animals received AMPH. ${ }^{*}$ In the animals with AAV.ER $\alpha$ transgene, asymmetrical rotational behavior induced by AMPH was greater on day 3 than on day $1(p<0.008)$ or $2(p<0.03)$. **In the animals with AAV.ER $\alpha$ transgene, asymmetrical rotational behavior induced by AMPH was greater than the control animals on all days $(p<0.015)$. Data are depicted as the mean \pm SEM.

Table 1. Mean number of rotations in both directions induced by $0.85 \mathrm{mg} / \mathrm{kg} \mathrm{AMPH}$ during $1 \mathrm{~h}$ of rotational behavior testing

\begin{tabular}{lllr}
\hline Group & $\begin{array}{l}\text { Total rotations } \\
\text { day } 1 \text { of AMPH }\end{array}$ & $\begin{array}{l}\text { Total rotations } \\
\text { day } 2 \text { of AMPH }\end{array}$ & $\begin{array}{l}\text { Total rotations } \\
\text { day } 3 \text { of AMPH }\end{array}$ \\
\hline AAV.ER $\alpha$ & $14.6 \pm 5.2^{a}$ & $172.3 \pm 44.2^{* *}$ & $141.7 \pm 26.1^{*}$ \\
AAV.ALP & $16.6 \pm 7.4$ & $128.2 \pm 27.1^{* *}$ & $93.2 \pm 12.4^{*}$ \\
\hline
\end{tabular}

${ }^{*} p<0.05$ compared with day $1 ;{ }^{* *} p<0.001$ compared with day 1 .

${ }^{a}$ Mean \pm SEM.

aging Products) was perfused through the probe for 10 min to mark the location of the dialysis probe in the tissue. After explant the probe was placed in ethanol for $5 \mathrm{~min}$ and then in aCSF. The probe was then calibrated using GABA standards that were heated to $37^{\circ} \mathrm{C}$.

\section{Immunocytochemistry}

At the completion of testing, animals were intracardially perfused with $4 \%$ paraformaldehyde and brains were stored in $30 \%$ sucrose at $4^{\circ} \mathrm{C}$. Sections were cut at $35 \mu \mathrm{m}$ and stored in cryoprotectant solution $(30 \%$ ethylene glycol, $30 \%$ sucrose in $0.1 \mathrm{M}$ PBS, pH 7.2) at $-20^{\circ} \mathrm{C}$ until immunocytochemistry. Then, sections were washed $4 \times 5 \mathrm{~min}$ w/PBS, followed by $\mathrm{NaBH}_{4}(1 \%)$ in PBS for $30 \mathrm{~min}$. After additional washes, sections were incubated in blocking serum with $4 \%$ normal goat serum (NGS), $0.2 \%$ Triton X-100 for 15-60 min, then transferred to incubate with the primary antibody at $4^{\circ} \mathrm{C}$ for $48 \mathrm{~h}(\mathrm{ER} \alpha \mathrm{H} 222$ antibody; courtesy Dr. G. Greene, University of Chicago, Chicago, IL) was used at 1:5000; antibody to green fluorescent protein (AbCam) was used at 1:25,000 to confirm expression of AAV.ALP and AAV.ER $\alpha$ in dialysis experiments). Sections were washed and then incubated in the secondary antibody (1:600), $2 \%$ NGS, and $0.2 \%$ Triton X-100 for $1 \mathrm{~h}$. After several washes the sections were transferred to the Vectastain $\mathrm{ABC}$ reagent (Vectastain Elite ABC kits, Vector Labs) solution for $1 \mathrm{~h}$. After washing, sites of antibodyantigen binding were visualized with the chromogen diaminobenzidine. Sections were mounted, dried, dehydrated and coverslipped.

\section{Western blots}

Immunoprecipitation and Western blot analysis for ER $\alpha$ were performed using striatal tissue from female rats, at 3 weeks post-OVX, according to previously published methods (Singh et al., 1999; ToranAllerand et al., 2002). Females were OVX to remove the endogenous source of estradiol which can induce variation in the number and intracellular location of ER. Western blots were derived from at least four independent experiments, a representative of which is shown in Figure 5. 
The specificity of the signal is determined by the apparent molecular weight of the protein detected, along with direct comparison with the appropriate protein lysate. Negative controls to test for the specificity of the interactions are performed by immunoprecipitation of the precleared protein lysates with mouse IgG, instead of specific antibodies.

\section{Statistical analyses}

Behavioral data were analyzed by two-way ANOVA with pairwise comparisons by the Bonferroni correction. Microdialysis data was analyzed by two-way ANOVA with repeated measures and planned paired $t$ tests.

\section{Results}

\section{Rotational behavior}

Animals that received the AAV.ER $\alpha$ in the dominant striatum made more net rotations (turns contralateral to the striatum with the AAV.ER $\alpha$ minus turns ipsiversive), both during the first $15 \mathrm{~min}$ (Fig. 1) and throughout the hour after receiving EB (data not shown), than did the control group $\left(F_{(1,21)}\right.$ $=14.48, p<0.001)$. These rats also turned more after the EB injection than after vehicle or during the habituation period $(p<0.01)$ (Fig. 1). The control animals did not exhibit a significant asymmetry in terms of net rotations. Thus, the introduction of the AAV.ER $\alpha$ in the striatum enhanced the slight endogenous asymmetry in the striatum, and transgene expression resulted in turning after treatment with EB.

When animals were tested with 0.85 mg/kg AMPH (Fig. 2) the AAV.ER $\alpha$ group again exhibited significantly more turning contralateral to the striatum with the AAV.ER $\alpha$ than did the AAV.ALP group (Group effect: $F_{(1,20)}=7.097, p<0.15$; Time effect $F_{(2,2)}=8.462, p<0.001$; Group $\times$ Time: $\left.F_{(2,40)}=3.363, p<0.05\right)$. As can be seen in Figure 2, there was only modest behavioral activation on the first day of testing in both groups, yet the AAV.ER $\alpha$ group exhibited greater rotational behavior than the control group $(p<0.015)$. On the second and third days of testing, the AAV.ER $\alpha$ group also exhibited significantly more turning than did the AAV.ALP group $(p<0.002)$. There was also significant sensitization of rotational behavior in the AAV.ER $\alpha$ group with animals turning more on day 3 than they did on day $1(p<0.008)$ or day $2(p<0.03)$.

The AAV.ALP group did not exhibit behavioral sensitization of rotational behavior contralateral to the side of the transgene implant. They did, however, show activation induced by AMPH (Table 1), and both groups exhibited an increase in the total number of rotations (contralateral + ipsilateral) over the $3 \mathrm{~d}$ of AMPH testing indicating sensitization of overall activity (Table 1). There were no differences between the groups in total rotations on any day. concentrations of GABA treated groups.
Table 2. The effects of viral vector expression, hormonal treatment, and exposure to $\mathrm{K}^{+}$on striatum dialysate

\begin{tabular}{llcc}
\hline Group & $\begin{array}{l}\text { Basal GABA in } \\
\mu \mathrm{M} \pm \mathrm{SEM}\end{array}$ & $\begin{array}{l}\text { GABA post-EB injection } \\
\text { in } \mu \mathrm{M} \pm \mathrm{SEM}\end{array}$ & $\begin{array}{c}\text { GABA postrecovery from } \\
\mathrm{K}^{+} \text {stimulation in } \mu \mathrm{M} \pm \mathrm{SEM}\end{array}$ \\
\hline AAV.ALP + OIL & $0.11 \pm 0.01$ & $0.109 \pm 0.008$ & $0.088 \pm 0.009$ \\
AAV.ALP + EB & $0.14 \pm 0.03$ & $0.12 \pm 0.02$ & $0.11 \pm 0.02$ \\
AAV.ER $\alpha+$ OIL & $0.10 \pm 0.01$ & $0.09 \pm 0.01$ & $0.08 \pm 0.01$ \\
AAV.ER $\alpha+$ EB & $0.10 \pm 0.02$ & $0.07 \pm 0.01$ & $0.07 \pm 0.02$ \\
\hline
\end{tabular}

Electropherograms were collected, and the mean dialysate concentration was obtained before (basal) and after (postinjection) an injection of $5 \mu \mathrm{g} E B$ or $01 \mathrm{~L}$ vehicle to OVX female rats. There was no main effect of treatment $\left(F_{(1,539)}=4.34, p=0.061\right)$ on basal GABA concentration and no interaction between treatment and time of sample collection $\left(F_{(49,539)}=0.68, p=0.949\right)$. Following recovery from the $\mathrm{K}^{+}$stimulation, the GABA dialysate concentration was also determined. Basal extracellular GABA concentrations in dialysate were compared with GABA dialysate concentrations post-EB injection and postrecovery in the same rats. Two-way ANOVA with repeated measures showed that that there was no main effect of treatment $\left(F_{(1,550)}=4.13, p=0.067\right)$ on poststimulation GABA dialysate concentration and no interaction between treatment and time of sample collection $\left(F_{(50,550)}=0.75, p=0.894\right)$.
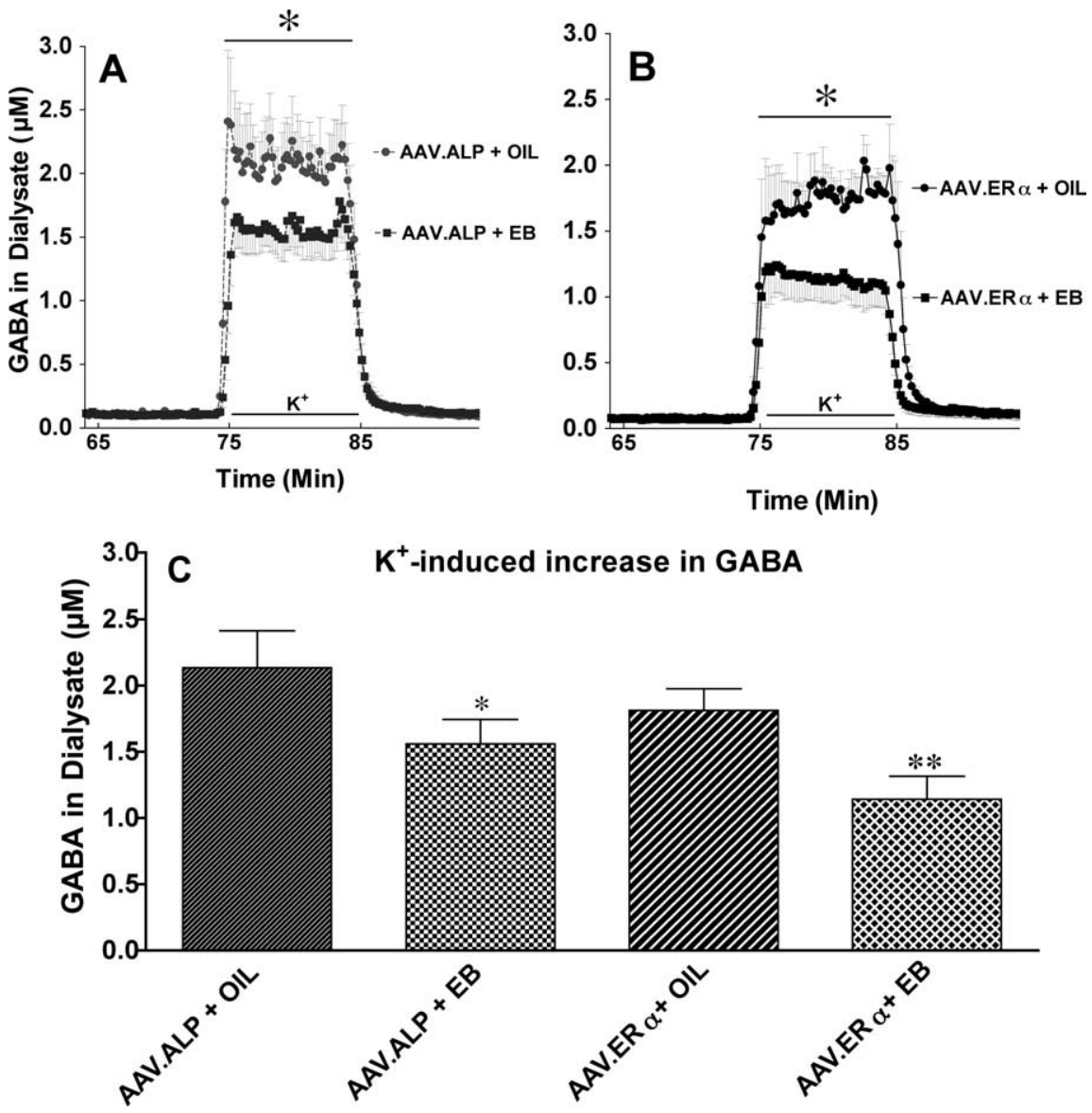

Figure 3. Effect of AAV.ALP or AAV.ER $\alpha$ and EB or OlL pretreatment on $\mathrm{K}^{+}$-evoked GABA in dialysate from striatum. $A$, The time course of the effect of AAV.ALP and EB or OIL pretreatment on $\mathrm{K}^{+}$-evoked GABA in dialysate from striatum. $\boldsymbol{B}$, The time course of the effect of AAV.ER $\alpha$ and EB or OIL pretreatment on $\mathrm{K}^{+}$-evoked GABA in dialysate from striatum. For $\boldsymbol{A}$ and $\boldsymbol{B}$, the bar depicts the period during which $\mathrm{K}^{+}$was dialyzed into striatum through the dialysis probe. *There was a main effect of treatment $\left(F_{(3,29)}=4.28, p<0.013\right)$, a treatment $\times$ time interaction $\left(F_{(29,426)}=2.94, p<0.0001\right)$; and an effect of time of sample collection $\left(F_{(29,142)}=126.37, p<0.0001\right)$. C, Effect of AAV.ALP or AAV.ER $\alpha$ and EB or OlL pretreatment on the mean \pm SEM increase in $\mathrm{K}^{+}$-evoked GABA in dialysate from striatum. ${ }^{*} A A V . A L P+E B$ less than AAV.ALP $+0 \mathrm{IL}(p<0.043) .{ }^{* *} \mathrm{AAV} . E R \alpha+E B$ less than AAV.ER $\alpha+$ OIL $(p<0.002)$, and AAV.ALP $+\operatorname{EB}(p<0.02)$. There was no significant difference between the oil

\section{Microdialysis}

During the microdialysis experiments the basal extracellular concentration of GABA did not differ among the four groups $\left(F_{(1,11)}\right.$ $=1.353, p=0.2694$ ) (Table 2). Furthermore, the basal extracellular GABA concentration was not significantly affected by treatment with $\mathrm{EB}$ or vehicle. Post- $\mathrm{K}^{+}$stimulation baseline values were also not statistically different (Table 2).

Local perfusion of $75 \mathrm{mM} \mathrm{K}^{+}$through the dialysis probe for 10 


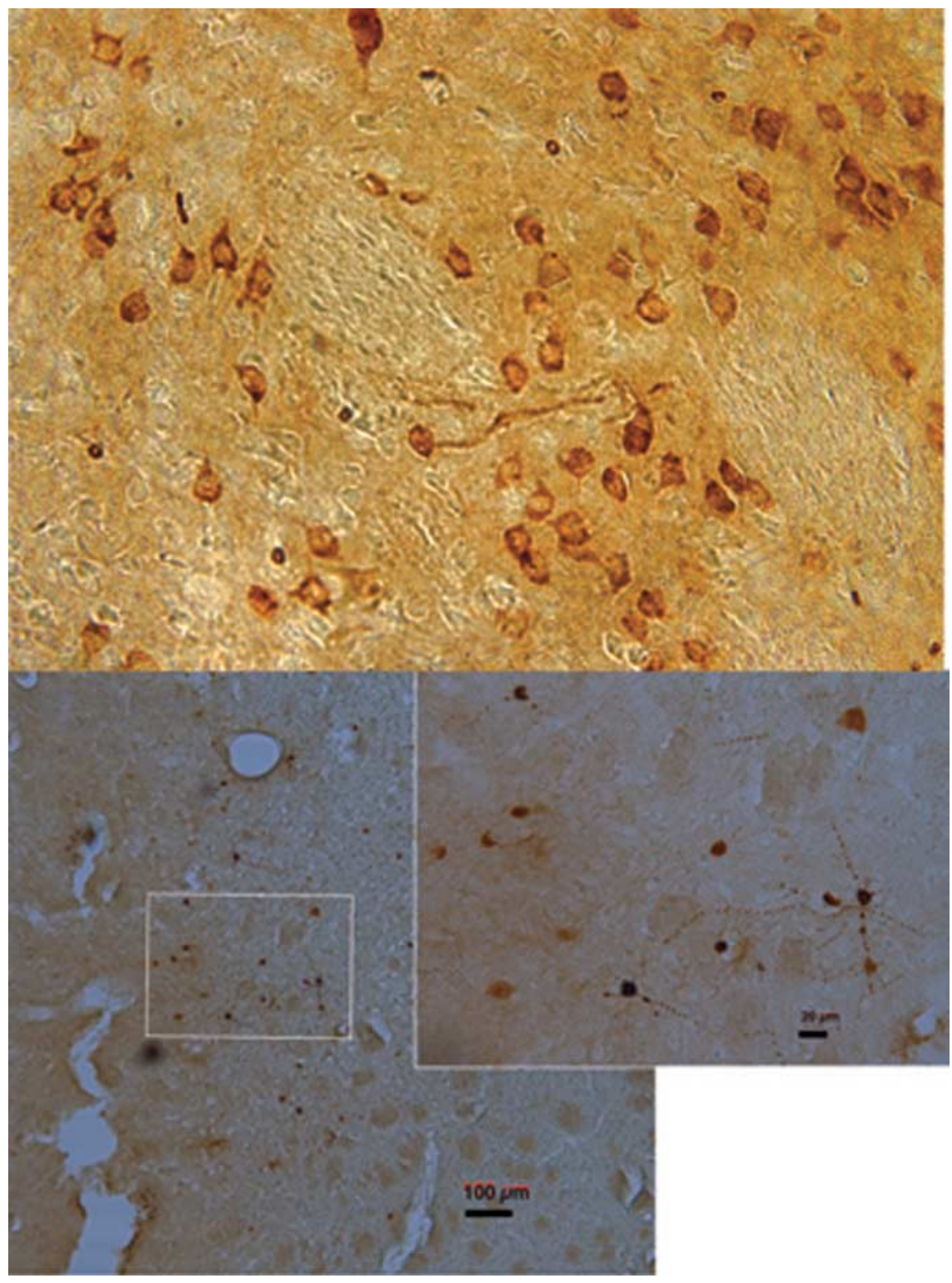

Figure 4. Expression of ER $\alpha$ (top) and GFP (bottom) in striatum after adeno-associated viral vector injection. Top, A representative image from an animal in the behavioral study. Bottom image is from an animal in the dialysis study; inset depicts cells with expression of GFP adjacent to the track. Magnification 40×; scale bars: bottom right, $100 \mu \mathrm{m}$; inset, $20 \mu \mathrm{m}$.

group, $t=3.191, p<0.002)$. There were no significant differences between the AAV.ER $\alpha+$ OIL and the AAV.ALP + OIL groups.

\section{Immunocytochemistry}

The expression of the AAV.ER $\alpha$ transgene in striatal neurons as indicated by immunocytochemistry for $\mathrm{ER} \alpha$ was confined primarily to the dorsolateral striatum exclusively on the side of the injection. Expression was quite variable in terms of the number of cells expressing the transduced genes, but expression was observed in all animals receiving the AAV.ER $\alpha$. Expression of $\operatorname{ER} \alpha$ was localized to the membrane/cytosol region of neurons, with most cells showing little nuclear staining (Fig. 4, top) and expression extending beyond the cell body into the surrounding processes. Animals that received AAV.ALP exhibited expression of GFP in the striatum (data not shown). For the microdialysis experiments, only animals with GFP expression around the dialysis probe (Fig. 4 , bottom) were included.

\section{Western blots}

Western blots were performed as a positive control to measure endogenous $\mathrm{ER} \alpha$ expression in the striatum. The blot indicated a low-level expression of $\operatorname{ER} \alpha$ in the membrane fraction from striatum of OVX rats (Fig. 5). ER $\alpha$ expression was higher in the cytosol/membrane fraction than the nuclear extract taken from homogenized striatal tissue.

\section{Discussion}

The expression of recombinant $\mathrm{ER} \alpha$ in the dorsolateral striatum resulted in enhanced turning contralateral to the side of the AAV.ER $\alpha$ expression compared with animals with AAV.ALP. Furthermore, animals with the AAV.ER $\alpha$ exhibited a greater estradiol-dependent attenuation of the $\mathrm{K}^{+}$-induced increase in GABA relative

min produced a transient increase of GABA in the extracellular fluid in all four groups of animals. Treatment with EB significantly attenuated the $\mathrm{K}^{+}$-induced increase in extracellular GABA concentration in dialysate (Fig. $3 A, B$ ). When results were analyzed by two-way ANOVA with repeated measures, there was a main effect of treatment $\left(F_{(3,29)}=4.28, p<0.013\right)$, a treatment $\times$ time interaction $\left(F_{(29,426)}=2.94, p<0.0001\right)$; and an effect of time of sample collection $\left(F_{(29,142)}=126.37, p<\right.$ 0.0001).

$t$ tests were planned a priori to compare differences between the group pairings. Importantly, the AAV.ER $\alpha+\mathrm{EB}$ group had significantly lower stimulated GABA release compared with the AAV.ALP + EB $(t=2.335, p<0.02)$ indicating that AAV.ER $\alpha$ enhanced the response to EB (Fig. 3). As previously shown, EB attenuated the $\mathrm{K}^{+}$-induced increase in GABA in both the AAV.ALP and AAV.ER $\alpha$ groups (AAV.ALP +EB vs AAV.ALP + OIL $, t=2.036, p<0.043$; AAV.ER $\alpha+$ EB vs AAV.ER $\alpha+$ OIL to controls. Coupling these behavioral and neurochemical results to the Western blot results showing expression of endogenous $\mathrm{ER} \alpha$ in striatum, these data suggest that endogenous $\mathrm{ER} \alpha$ in striatum may enhance the striatal DA response to estradiol, and this effect may be mediated by an attenuation of GABA release resulting in a release of inhibition on DA terminals.

Striatal GABAergic neurons are known to have recurrent collaterals that have synapses in close proximity to DA terminals (Sizemore et al., 2004). GABA release onto $\mathrm{GABA}_{\mathrm{B}}$ receptors located on DA presynaptic terminals tonically inhibits DA release in the striatum (Smolders et al., 1995; Charara et al., 2000). This inhibition of DA release mediated via $\mathrm{GABA}_{\mathrm{B}}$ receptors on $\mathrm{DA}$ terminals is thought to be due to inactivation of voltagedependent $\mathrm{Ca}^{2+}$ channels on the presynaptic terminal (Cardozo and Bean, 1995). Combining these anatomical results along with electrophysiology (Mermelstein et al., 1996) and microdialysis 


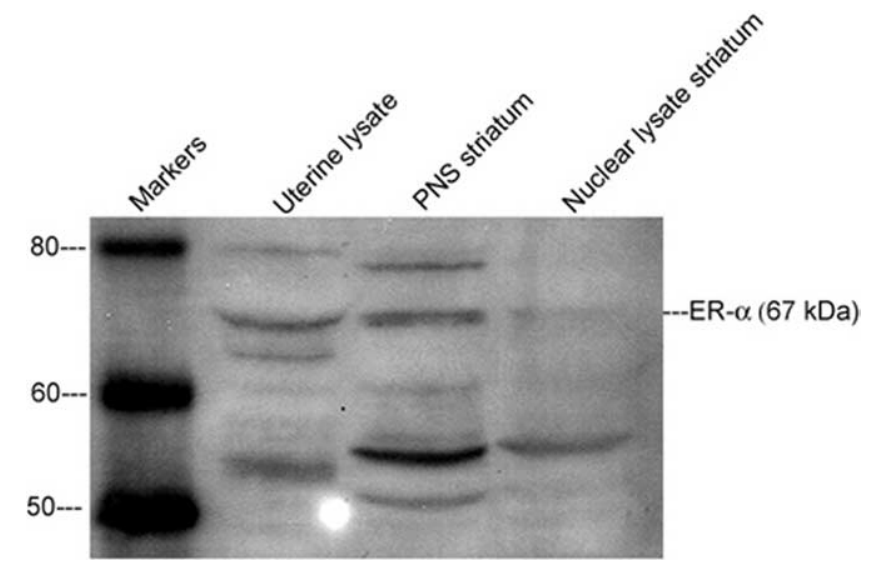

Figure 5. Western blot using an antibody to ER- $\alpha$ (Millipore, (-1355) with $100 \mu$ g protein from striatal tissue obtained from female rats 3 weeks post-0VX showing the presence of ER- $\alpha$ in the membrane fraction (labeled PNS) from striatum

(Hu et al., 2006) data showing the inhibitory effects of estradiol on GABAergic neurons suggests a linkage between the DA enhancing effects of estradiol and the reduction in GABA release. The twofold increase in attenuation of $\mathrm{K}^{+}$-evoked GABA seen with $\mathrm{ER} \alpha$ overexpression suggests that this receptor plays a role in linking these two neurotransmitter systems in the striatum. The decrease in GABA release is hypothesized to result in a release of inhibition, which enhances DA release when DA neurons are activated (for discussion, see Becker and $\mathrm{Hu}, 2008$; Becker and Taylor, 2008). Thus, when behaviorally active rats receive estradiol, we postulate that there is an enhanced release of DA on the side of the striatum with the $\operatorname{AAV} . \operatorname{ER} \alpha$, relative to the other striatum, and animals turn in circles away from the more active side.

Behavioral sensitization to AMPH occurs due to long-term changes in DA neurons. The activation of DA systems is necessary to induce sensitization with AMPH, and behavioral sensitization is prevented by cotreatment with DA antagonists, given either systemically or directly into the ventral tegmental area (Kuczenski and Leith, 1981; Vezina and Stewart, 1989; Weiss et al., 1989). The evidence implicating D1 receptors is quite strong, although the involvement of D2 receptors is more controversial (White and Wolf, 1991; Stewart and Badiani, 1993). When AAV.ER $\alpha$ injected animals treated with estradiol receive AMPH, they exhibit sensitization of rotational behavioral in the direction away from the striatum with the transgene. Both groups showed enhanced total rotations on the second test day although they did not receive additional estradiol treatment before AMPH. This is likely due to the combined effects of the neural changes associated with sensitization and the residual serum estradiol which was still elevated at the time of the second AMPH test. Interestingly, only the AAV.ER $\alpha$ animals showed a greater rotational behavior in the direction away from the side of the transgene expression. We hypothesize that the sensitization relative to the side of the transgene in the animals with the AAV.ER $\alpha$ is caused by enhanced postsynaptic changes due to either greater DA release on the side of the transgene expression, or the effects of ER $\alpha$ transgene expression in the postsynaptic cell, or both processes. The control animals did not exhibit sensitization of rotational behavior contralateral to the control transgene implant, but they did exhibit an increase in total rotations. Thus, both groups showed behavioral sensitization, but in the AAV.ER $\alpha$ group the transgene apparently enhanced activity in the striatum on the side containing the transgene resulting in an asymmetry in the striatal response to AMPH. Since rotational behavior is related to the magnitude of the asymmetry in striatal DA (Robinson and Becker, 1986), this is indirect evidence of enhanced DA activity.

Studies to identify where estradiol acts in the brain of adult rats have previously reported that the striatum is not an area that concentrates estradiol in the nucleus or that expresses ER $\alpha$ mRNA (Pfaff and Keiner, 1973; Shughrue et al., 1997). However, $\mathrm{ER} \alpha$ mRNA is present in the striatum during development at days 10-12 in the female rat, and there is specific binding to ER at this time (Toran-Allerand et al., 1992). In animals expressing AAV.ER $\alpha$, shown in Figure 4, it is intriguing that there is little nuclear localization of the ER $\alpha$. This suggests that the protein is treated differently in the striatum than in other brain regions (e.g., in the ventromedial hypothalamus) where expression is seen primarily in the nucleus (Musatov et al., 2007). Immunocytochemistry for $\mathrm{ER} \alpha$ protein in the striatum of control rats finds low levels of protein immunoreactvity associated with striatal neuronal membranes of females (preliminary results from the Becker laboratory), but with the high background seen in striatum, images are not conclusive in animals not expressing $\mathrm{ER} \alpha$. Our results from Western blots indicate that there is a low level of endogenous $\mathrm{ER} \alpha$ expression in striatum.

It is now apparent that all steroid hormones can have both long-term and rapid effects on target tissues (Hammes, 2003). The intracellular receptors mediating the long-term effect of steroid hormones through initiation of transcription have been known for many years (Greene et al., 1986). Alternate forms of estradiol receptors have also been identified that include ER $\beta$ (Kuiper et al., 1996) and ER-X (Toran-Allerand et al., 2002; Toran-Allerand, 2004, 2005). Furthermore, there is now evidence for functional interaction between the membrane and nuclear receptors (Levin, 2005; Pedram et al., 2006).

The recent finding that there are membrane progestin receptors in fish, with homologous genes found in humans and mice raises the possibility that there may be other families of receptors involved in the rapid signaling effects of other steroid hormones as well (Zhu et al., 2003a,b). These novel progestin receptors code proteins that appear to have seven transmembrane domains characteristic of G-protein-coupled receptors. Further research will be required to determine if there are estrogen receptors homologous to these progestin receptors.

Results reported here are consistent with a role for $\operatorname{ER} \alpha$ in mediating the rapid behavioral and neurochemical effects of estradiol in the striatum. It is possible that other ERs may participate in the endogenous effects of estradiol in the striatum. The results reported here demonstrate that over-expressed ER $\alpha$ enhances the behavioral and neurochemical effects of estradiol that are usually seen. These results support the idea that $\operatorname{ER} \alpha$ is involved in the effect of estradiol on striatal-mediated behaviors.

\section{References}

Becker JB (1990a) Direct effect of $17 \beta$-estradiol on striatum: sex differences in dopamine release. Synapse 5:157-164.

Becker JB (1990b) Estrogen rapidly potentiates amphetamine-induced striatal dopamine release and rotational behavior during microdialysis. Neurosci Lett 118:169-171.

Becker JB, Hu M (2008) Sex differences in drug abuse. Front Neuroendocrinol 29:36-47.

Becker JB, Taylor JR (2008) Sex differences in motivation. In: Sex differences in the brain: from genes to behavior (Becker JB, Berkley K, Geary N, Hampson E, Herman JP, Young EA, eds), pp 177-199. Oxford: Oxford UP.

Becker JB, Robinson TE, Lorenz KA (1982) Sex differences and estrous cycle 
variations in amphetamine-elicited rotational behavior. Eur J Pharmacol 80:65-72.

Boulware MI, Kordasiewicz H, Mermelstein PG (2007) Caveolin proteins are essential for distinct effects of membrane estrogen receptors in neurons. J Neurosci 27:9941-9950.

Bowser MT, Kennedy RT (2001) In vivo monitoring of amine neurotransmitters using microdialysis with on-line capillary electrophoresis. Electrophoresis 22:3668-3676.

Butcher RL, Collins WE, Fugo NW (1974) Plasma concentration of LH, FSH, prolactin, progesterone and estradiol $-17-\beta$ throughout the 4-day estrous cycle of the rat. Endocrinology 94:1704-1708.

Cardozo DL, Bean BP (1995) Voltage-dependent calcium channels in rat midbrain dopamine neurons: modulation by dopamine and GABAB receptors. J Neurophysiol 74:1137-1148.

Castner SA, Xiao L, Becker JB (1993) Sex differences in striatal dopamine: in vivo microdialysis and behavioral studies. Brain Res 610:127-134.

Charara A, Heilman TC, Levey AI, Smith Y (2000) Pre- and postsynaptic localization of GABA(B) receptors in the basal ganglia in monkeys. Neuroscience 95:127-140.

Clark KR, Liu X, McGrath JP, Johnson PR (1999) Highly purified recombinant adeno-associated virus vectors are biologically active and free of detectable helper and wild-type viruses. Hum Gene Ther 10:1031-1039.

Greene GL, Gilna P, Waterfield M, Baker A, Hort Y, Shine J (1986) Sequence and expression of human estrogen receptor complementary DNA. Science 231:1150-1154.

Hammes SR (2003) The further redefining of steroid-mediated signaling. Proc Natl Acad Sci U S A 100:2168-2170.

Hu M, Becker JB (2003) Effects of sex and estrogen on behavioral sensitization to cocaine in rats. J Neurosci 23:693-699.

Hu M, Becker JB (2008) Acquisition of cocaine self-administration in ovariectomized female rats: effect of estradiol dose or chronic estradiol administration. Drug Alcohol Depend 94:56-62.

Hu M, Crombag HS, Robinson TE, Becker JB (2004) Biological basis of sex differences in the propensity to self-administer cocaine. Neuropsychopharmacology 29:81-85.

Hu M, Watson CJ, Kennedy RT, Becker JB (2006) Estradiol attenuates the $\mathrm{K}+$-induced increase in extracellular GABA in rat striatum. Synapse 59:122-124.

Jackson LR, Robinson TE, Becker JB (2006) Sex differences and hormonal influences on acquisition of cocaine self-administration in rats. Neuropsychopharmacology 31:129-138.

Jerussi TP, Glick SD (1976) Drug-induced rotation in rats without lesions: behavioral and neurochemical indices of a normal asymmetry in nigrostriatal function. Psychopharmacology (Berl) 47:249-260.

Kuczenski R, Leith NJ (1981) Chronic amphetamine: Is dopamine a link in or mediator of the development of tolerance or reverse tolerance? Pharmacol Biochem Behav 15:405-413.

Kuiper GG, Enmark E, Pelto-Huikko M, Nilsson S, Gustafsson JA (1996) Cloning of a novel estrogen receptor expressed in rat prostate and ovary. Proc Natl Acad Sci U S A 93:5925-5930.

Levin ER (2005) Integration of the extranuclear and nuclear actions of estrogen. Mol Endocrinol 19:1951-1959.

Mermelstein PG, Becker JB, Surmeier DJ (1996) Estradiol reduces calcium currents in rat neostriatal neurons via a membrane receptor. J Neurosci 16:595-604.

Micevych PE, Mermelstein PG (2008) Membrane estrogen receptors acting through metabotropic glutamate receptors: an emerging mechanism of estrogen action in brain. Mol Neurobiol 38:66-77.

Musatov S, Chen W, Pfaff DW, Mobbs CV, Yang XJ, Clegg DJ, Kaplitt MG, Ogawa S (2007) Silencing of estrogen receptor alpha in the ventromedial nucleus of hypothalamus leads to metabolic syndrome. Proc Natl Acad Sci U S A 104:2501-2506.

Pedram A, Razandi M, Levin ER (2006) Nature of functional estrogen receptors at the plasma membrane. Mol Endocrinol 20:1996-2009.

Pfaff D, Keiner M (1973) Atlas of estradiol-concentrating cells in the central nervous system of the rat. J Comp Neurol 151:121-158.

Razandi M, Alton G, Pedram A, Ghonshani S, Webb P, Levin ER (2003) Identification of a structural determinant necessary for the localization and function of estrogen receptor alpha at the plasma membrane. Mol Cell Biol 23:1633-1646.

Robinson TE, Becker JB (1986) Enduring changes in brain and behavior produced by chronic amphetamine administration: a review and evaluation of animal models of amphetamine psychosis. Brain Res 396:157-198.

Samulski RJ, Chang LS, Shenk T (1987) A recombinant plasmid from which an infectious adeno-associated virus genome can be excised in vitro and its use to study viral replication. J Virol 61:3096-3101.

Shughrue PJ, Lane MV, Merchenthaler I (1997) Comparative distribution of estrogen receptor-alpha and -beta mRNA in the rat central nervous system. J Comp Neurol 388:507-525.

Singh M, Sétáló G Jr, Guan X, Warren M, Toran-Allerand CD (1999) Estrogen-induced activation of mitogen-activated protein kinase in cerebral cortical explants: convergence of estrogen and neurotrophin signaling pathways. J Neurosci 19:1179-1188.

Sizemore GM, Co C, Koves TR, Martin TJ, Smith JE (2004) Timedependent recovery from the effects of 6-hydroxydopamine lesions of the rat nucleus accumbens on cocaine self-administration and the levels of dopamine in microdialysates. Psychopharmacology 171:413-420.

Smolders I, De Klippel N, Sarre S, Ebinger G, Michotte Y (1995) Tonic GABA-ergic modulation of striatal dopamine release studied by in vivo microdialysis in the freely moving rat. Eur J Pharmacol 284:83-91.

Stewart J, Badiani A (1993) Tolerance and sensitization to the behavioral effects of drugs. Behav Pharmacol 4:289-312.

Toran-Allerand CD (2004) Minireview: a plethora of estrogen receptors in the brain: where will it end? Endocrinology 145:1069-1074.

Toran-Allerand CD (2005) Estrogen and the brain: beyond ER-alpha, ERbeta, and 17beta-estradiol. Ann N Y Acad Sci 1052:136-144.

Toran-Allerand CD, Miranda RC, Hochberg RB, MacLusky NJ (1992) Cellular variations in estrogen receptor mRNA translation in the developing brain: evidence from combined [125I] estrogen autoradiography and non-isotopic in situ hybridization histochemistry. Brain Res 576:25-41.

Toran-Allerand CD, Guan X, MacLusky NJ, Horvath TL, Diano S, Singh M, Connolly ES Jr, Nethrapalli IS, Tinnikov AA (2002) ER-X: a novel, plasma membrane-associated, putative estrogen receptor that is regulated during development and after ischemic brain injury. J Neurosci 22:8391-8401.

Veldwijk MR, Topaly J, Laufs S, Hengge UR, Wenz F, Zeller WJ, Fruehauf S (2002) Development and optimization of a real-time quantitative PCRbased method for the titration of AAV-2 vector stocks. Mol Ther 6:272-278.

Vezina P, Stewart J (1989) The effect of dopamine receptor blockade on the development of sensitization to the locomotor activating effects of amphetamine and morphine. Brain Res 499:108-120.

Vigh J, Lasater EM (2004) L-type calcium channels mediate transmitter release in isolated, wide-field retinal amacrine cells. Vis Neurosci 21:129-134.

Wade CB, Dorsa DM (2003) Estrogen activation of cyclic adenosine 5 '-monophosphate response element-mediated transcription requires the extracellularly regulated kinase/mitogen-activated protein kinase pathway. Endocrinology 144:832-838.

Weiss SR, Post RM, Pert A, Woodward R, Murman D (1989) Contextdependent cocaine sensitization: differential effect of haloperidol on development versus expression. Pharmacol Biochem Behav 34:655-661.

White FJ, Wolf ME (1991) Psychomotor stimulants. In: The biological bases of drug tolerance and dependence (Pratt J, ed), pp 153-197. New York: Academic.

Whitehead KJ, Rose S, Jenner P (2001) Involvement of intrinsic cholinergic and GABAergis innervation in the effect of NMDA on striatal dopamine efflux and metabolism as assessed by microdialysis in freely moving rats. Eur J Neurosci 14:851-860.

Xiao L, Becker JB (1998) Effects of estrogen agonists on amphetaminestimulated striatal dopamine release. Synapse 29:379-391.

Xiao L, Jackson LR, Becker JB (2003) The effect of estradiol in the striatum is blocked by ICI 182,780 but not tamoxifen: pharmacological and behavioral evidence. Neuroendocrinology 77:239-245.

Zhu Y, Bond J, Thomas P (2003a) Identification, classification, and partial characterization of genes in humans and other vertebrates homologous to a fish membrane progestin receptor. Proc Natl Acad Sci U SA 100:2237-2242.

Zhu Y, Rice CD, Pang Y, Pace M, Thomas P (2003b) Cloning, expression, and characterization of a membrane progestin receptor and evidence it is an intermediary in meiotic maturation of fish oocytes. Proc Natl Acad Sci U S A 100:2231-2236. 